\title{
Normoglycaemic, Normolipidaemic and Antioxidant Effects of Ethanolic Extract of Acacia ataxacantha Root in Streptozotocin - induced Diabetic Rats
}

\author{
Rotimi O. ARISE ${ }^{1 *}$, Tosan AKAPA ${ }^{1}$, Moshood A. ADIGUN ${ }^{1}$, \\ Abeeb A. YEKEEN ${ }^{1}$, Oluwafemi O. OGUNTIBEJU ${ }^{2}$ \\ ${ }^{1}$ University ofIlorin, Faculty of Life Sciences, Department of Biochemistry, Ilorin, Nigeria; ariserotimi@gmailcom (*orresponding author); \\ tosanakapa@gmail.com;moshlat37@yahoo.com;abeeb.yekeen@hotmail.com \\ ${ }^{2}$ Cape Peninsula University of Technology, Faculty of Health \& Wellness Sciences, Department of Biomedical Sciences, \\ SouthAfrica;oguntibejuo@cputacza;bejufemi@yahoo.co.uk
}

\begin{abstract}
The antidiabetic, normolipidaemic, antioxidant and safety evaluations of ethanolic extract of Acacia ataxacantha roots (EEAAR) were investigated in streptozotocin - induced diabetic rats, to verify its use in traditional African medicine and as alternative to synthetic normoglycaemic agents in diabetic treatments. Thirty albino rats (Rattus novergicus) were randomized into six groups - control, diabetic control, EEAAR-treated at $125 \mathrm{mg} / \mathrm{kg}, 250 \mathrm{mg} / \mathrm{kg}, 500 \mathrm{mg} / \mathrm{kg}$ body weights (b.wts.) and metformin groups, respectively. Phytochemical screening showed the presence of alkaloids, polyphenols, flavonoid, saponins, tannins and terpenoid. Blood glucose was significantly reduced $(\mathrm{p}<0.05)$ especially after 7 days of oral administration of EEAAR at $125 \mathrm{mg} / \mathrm{kg}$ b.wt with values $(110.01 \pm 9.64 \mathrm{mg} / \mathrm{dl})$ similar to that of the control $(106.33 \pm 4.13 \mathrm{mg} / \mathrm{dl})$. There was an increase $(\mathrm{p}<0.05)$ in the ALT and AST activities of the liver and serum of rats in all the groups except in those that received $125 \mathrm{mg} / \mathrm{kg}$ b.wt. Serum total cholesterol, low density lipoprotein cholesterol and triglyceride were decreased ( $\mathrm{p}<$ $0.05)$ upon administration of the extract and metformin. There was no difference $(\mathrm{p}>0.05)$ in malondialdehyde concentration of rats administered with $125 \mathrm{mg} / \mathrm{kg}$ b.wt. of extract and metformin. Superoxide dismutase activity was elevated $(\mathrm{p}<0.05)$ in all groups and compared favourably with the control in each of the tissues. This study revealed the antidiabetic and hypolipidaemic effects of EEAAR, which may be due to the antioxidant properties of some of the phytochemical constituents. However, the extract may not be safe at large and repeated doses.
\end{abstract}

Keywords: Acacia ataxacantha, flame thorn, metformin, normoglyceamic, normolipideamic

Abbreviations: ALT - alanine aminotransferase, AST - aspartate aminotransferase, b.wt. - body weight, EEAAR - ethanolic extract of Acacia ataxacantha roots, MDA - malondialdehyde

\section{Introduction}

Diabetes is a group of metabolic diseases characterized by hyperglycaemia resulting from defects in insulin secretion, insulin action or both (American Diabetes Association, 2012). Hyperglycaemia and hyperlipidaemia are two important characters of diabetes mellitus. Diabetic patients experience various vascular complications, such as atherosclerosis, diabetic nephropathy and neuropathy, retinopathy, angiopathy and several others (Sheetz, 2002; Maritim et al., 2003). Excessive oxidative stress has been implicated in the pathology and complications of diabetes mellitus (Wolff, 1967). International Diabetic Federation (IDF) reported in 2011 that many regions of Asia and Africa show a high prevalence of the disease, while the incidence is increasing in East and North Africa where six of the ten countries had the highest prevalence of diabetes in the world.

Hyperglycaemia can be handled initially with oral synthetic agents and insulin therapy, but these synthetic agents produce some serious side effects and are relatively expensive for developing countries (Kumar et al., 2011a). The toxicity of oral antidiabetic agents differs widely in clinical manifestations, severity and treatment (Kumar et al., 2011b). In addition, certain oral hypoglycaemic agents are not effective in lowering the blood sugar in chronic diabetic patients. The global information on ethnobotanicals includes about 800 medicinal plants used for controlling diabetic mellitus and associated diseases conditions (Jerald $e t$ al., 2009). Dietary management includes the use of traditional medicines that are mainly derived from plants (Gayathri and Kannabiran, 2008). Even now, 
approximately $80 \%$ of the third world population is almost entirely dependent on traditional medicines. Numerous traditional medicinal plants such as Hemidesmus indicus (Gayathri and Kannabiran, 2008), Vernonia anthelmintica (Fatima et al., 2010), Pterocarpus marsupus (Maruthupandian and Mohan, 2011), Eugenia floccosa (Kala et al., 2012a), Eugenia singamattina (Kala et al., 2012b), Psidium guajava (Shakeera et al., 2013) etc. have been reported to have normoglycemic properties.

Acacia ataxacantha (family: Fabaceae, otherwise called Flame thorn) is an African tree species with conspicuous red pods and numerous hooked prickles. It is widespread in subSaharan Africa from Senegal in the West to Sudan in the East, Namibia, Botswana, Zimbabwe, and in the Transvaal and KwaZulu-Natal and some Northern parts of Nigeria. Its normal habit is that of a multi-stemmed, untidy, large shrub with a tendency for the shoots to scramble using their recurved prickles and often develops into a single-stemmed tree of $5-10 \mathrm{~m}$ in height and $300 \mathrm{~mm}$ trunk diameter. Flowers occur as clusters of off-white or cream-coloured terminal spikes which are fragrant and bloom during spring and summer (Lynette and Barbara, 1981). There are however, no reports on the normoglycemic, normolipidaemic and antioxidant activities of $A$. ataxacantha roots. This study thus, investigated the normoglycemic, normolipidaemic and antioxidant activities of $A$. ataxacantha root ethanolic extract in streptozotocin - induced diabetic rats.

\section{Materials and Methods}

\section{Collection of Acacia ataxacantha}

The roots of Acacia ataxacantha were collected in September, 2012, from a farmland in Uruan, Kano State, Nigeria. The plant was identified and authenticated at the Herbarium of the Department of Plant Biology, University of Ilorin, Ilorin, Nigeria, where voucher number 892 was deposited for future references.

\section{Experimental animal}

Thirty male albino rats (Rattus norvegicus) with an average weight of $158 \pm 2.19 \mathrm{~g}$ were obtained from the Animal Holding Unit of the Department of Biochemistry, Faculty of Life Sciences, University of Ilorin, Ilorin, Nigeria. The animals were housed in clean cages, placed in wellventilated house conditions (temperature $28-31{ }^{\circ} \mathrm{C}$; photoperiod $12 \mathrm{~h}$ light and $12 \mathrm{~h}$ dark; humidity 55-60\%) at the Department of Biochemistry, Faculty of Life Sciences, University of Ilorin. They were given standard food pellets and allowed drinking water ad libitum. All animals were carefully monitored and maintained in accordance with ethical recommendations and directives of EU Directives 2010/63/ EU for animal experiments.

\section{Preparation of ethanolic extract of $A$. ataxacanth a root}

The ethanolic extract of $A$. ataxacantha root (EEAAR) was prepared by soxhletion. The powdered plant material $(250 \mathrm{~g})$ was repeatedly extracted in a $1,000 \mathrm{ml}$ round bottomed flask with $500 \mathrm{ml}$ ethanol (95\%). The reflux time for each solvent was 40 cycles for complete extraction. The extracts were cooled at room temperature, filtered and evaporated to dryness under reduced pressure in a rotary evaporator and kept under refrigeration at $-4{ }^{\circ} \mathrm{C}$ till further use. The extract was prepared daily for each administration over the seven-day experimental period, $1.25 \mathrm{mg} / \mathrm{ml}, 2.50$ $\mathrm{mg} / \mathrm{ml}$ and $5 \mathrm{mg} / \mathrm{ml}$ doses were prepared to deliver daily 125 $\mathrm{mg} / \mathrm{kg}, \quad 250 \mathrm{mg} / \mathrm{kg}$ and $500 \mathrm{mg} / \mathrm{kg}$ body weight concentrations respectively to rats.

\section{Induction of experimental diabetes}

Diabetes was induced by intra-peritoneal injection of 65 $\mathrm{mg} / \mathrm{kg}$ body weight of streptozotocin (STZ), Batch No. U925 obtained from Sigma St. Louis, M.O. USA. Prior to diabetes induction, the animals were fasted for 12 hours. Confirmation of diabetes was done 48 hours after induction using One Touch glucometer (Lifescan Inc 1995 Milpas, California, USA). Blood sample for the fasting blood sugar (FBS) determination was obtained from tail puncture of the rats, and animals with $\mathrm{FBS} \geq 200 \mathrm{mg} / \mathrm{dl}$ were considered diabetic, thus included in the study as diabetic animals and blood sugar level was checked every 2 days.

\section{Animal grouping and treatments}

Thirty albino rats (Rattus norvegicus) were used for the experiment. The environment was kept cleaned and disinfected. The rats were acclimatized for one week and were given standard rodent diet and water ad libitum. The weights of the rats were taken after fasting them for $12 \mathrm{hrs}$ prior to the commencement of the experiment. The rats were randomly distributed into six treatment groups of five rats each.

Group A: Rats administered only distilled water (normal control)

Group B: Rats in this group were diabetic and untreated (diabetic control)

Group C: Rats administered EEAAR at a dose of $125 \mathrm{mg} / \mathrm{kg}$ body weight

Group D: Rats administered EEAAR at a dose of $250 \mathrm{mg} / \mathrm{kg}$ body weight

Group E: Rats administered EEAAR at a dose of $500 \mathrm{mg} / \mathrm{kg}$ body weight

Group F: Rats administered reference antidiabetic drug (metformin at $10 \mathrm{mg} / \mathrm{kg}$ body weight)

\section{Preparation of serum and tissue homogenates}

The procedure described by Yakubu et al. (2005) was employed. Briefly, under ether anaesthesia, the veins after being slightly displaced (to prevent blood contamination by interstitial fluid) were cut with a sterile scalpel blade and 5 $\mathrm{ml}$ of the blood was collected into clean dry centrifuge tubes. The blood was then left undisturbed to clot for 10 minutes at room temperature. The tubes were thereafter centrifuged for 15 minutes using Uniscope Laboratory centrifuge (Model SM800B, Surgifriend Medicals, Essex, England). The sera were aspirated with Pasteur pipettes into dry sample bottles and used within 12 hours of preparation for the biochemical assays. The liver, kidney and pancreas were also carefully removed, and placed in ice-cold $0.25 \mathrm{M}$ sucrose solution to maintain the integrity of the tissues. The organs were blotted with tissue paper, weighed and homogenized in ice-cold $0.25 \mathrm{M}$ sucrose solution using homogenizer. 
146

\section{Determination of biochemical parameters}

The method described by Reitman and Frankel (1957) was used for the assay of ALT and AST activities. Malondialdehyde (MDA) concentration was assayed using the method described by Varshney and Kale (1990) and superoxide dismutase activity was determined by the method of Misra and Fridovich (1972). Serum urea was determined by the method described by Varley (1976) and serum creatinine by the method described by Owen et al. (1954). Total cholesterol, triglyceride, high density lipoprotein cholesterol and low density lipoprotein cholesterol were assayed using the method of Zlakis et al. (1953), Foster and Dunn (1973), Burstein et al. (1970) and Friedewald et al. (1972) respectively.

\section{Statistical analysis}

All data are expressed as mean of five replicates \pm standard deviation (SD). Statistical evaluation of data was performed by SPSS version 16 using one-way analysis of variance (ANOVA), followed by Dunett's posthoc test for multiple comparison. Values were considered statistically significant at $\mathrm{p}<0.05$ (confidence level $=95 \%$ ).

\section{Results}

Secondary metabolite constituents of ethanolic extract of $A$. ataxacantha root

The secondary metabolite constituents present in EEAAR include alkaloids, polyphenols, flavonoids, saponins, tannins, terpenoids; however, glycoside was not detected (Table 1).

Table 1. Secondary metabolite constituents of Acacia ataxacantha root

\begin{tabular}{lc}
\hline Secondary metabolite & Extract \\
\hline Alkaloids & + \\
Polyphenols & + \\
Flavonoids & + \\
Saponins & + \\
Glycosides & - \\
Tannins & + \\
Terpenoids & + \\
\hline
\end{tabular}

Keys: Presence of constituents (+); Absence of constituents (-)

Table 2. Effect of daily administration of EEAAR for seven days on fasting blood glucose of streptozotocin - induced diabetic rats

\begin{tabular}{lccc}
\hline \multirow{2}{*}{ Groups } & \multicolumn{3}{c}{ Glucose level (mg/dl) } \\
\cline { 2 - 4 } & Day 1 & Day 3 & Day 7 \\
\hline Control & $99.00 \pm 2.05^{\mathrm{a}}$ & $90.33 \pm 5.03^{\mathrm{a}}$ & $106.33 \pm 4.13^{\mathrm{a}}$ \\
Diabetic control & $284.00 \pm 10.15^{\mathrm{b}}$ & $302.00 \pm 12.14^{\mathrm{b}}$ & $310.00 \pm 19.46^{\mathrm{b}}$ \\
\hline $125 \mathrm{mg} / \mathrm{kg} \mathrm{b.wt.}$ & $296.00 \pm 9.50^{\mathrm{b}}$ & $222.33 \pm 10.60^{\mathrm{b}}$ & $110.01 \pm 9.64^{\mathrm{a}}$ \\
EEAAR & & & \\
$250 \mathrm{mg} / \mathrm{kg}$ b.wt. & $242.00 \pm 21.00^{\mathrm{b}}$ & $241.16 \pm 24.23^{\mathrm{b}}$ & $226.00 \pm 18.23^{\mathrm{b}}$ \\
EEAAR & & & \\
$500 \mathrm{mg} / \mathrm{kg}$ b.wt. & $274.14 \pm 26.13^{\mathrm{b}}$ & $434.00 \pm 13.52^{\mathrm{b}}$ & $429.00 \pm 28.48^{\mathrm{b}}$ \\
$\begin{array}{l}\text { EEAAR } \\
10 \mathrm{mg} / \mathrm{kg} \text { b.wt. } \\
\text { metformin }\end{array}$ & $120.00 \pm 15.00^{\mathrm{b}}$ & $100.00 \pm 6.87^{\mathrm{a}}$ & $103.05 \pm 5.10^{\mathrm{a}}$ \\
\hline
\end{tabular}

Values are mean \pm SD for $n=5$, column values with different superscripts are significantly different $(\mathrm{p}<0.05)$ when compared to the control
Table 3. Effect of administration of EEAAR daily for seven days on kidney function indices of streptozotocin-induced diabetic rats

\begin{tabular}{ccccccc}
\hline & \multicolumn{6}{c}{ Groups } \\
\cline { 2 - 7 } $\begin{array}{c}\text { Parameter } \\
(\mathrm{mg} / \mathrm{dl})\end{array}$ & Control & $\begin{array}{c}\text { Diabetic } \\
\text { control }\end{array}$ & $\begin{array}{c}125 \\
\mathrm{mg} / \mathrm{kg} \\
\text { b.wt }\end{array}$ & $\begin{array}{c}250 \mathrm{mg} / \mathrm{kg} \\
\text { b.wt }\end{array}$ & $\begin{array}{c}500 \mathrm{mg} / \mathrm{kg} \\
\text { b.wt }\end{array}$ & $\begin{array}{c}10 \mathrm{mg} / \mathrm{kg} \\
\text { b.wt } \\
\text { metformin }\end{array}$ \\
\hline Creatinine & $3.36 \pm$ & $5.62 \pm$ & $3.60 \pm$ & $5.33 \pm$ & $6.30 \pm$ & $3.45 \pm$ \\
& $0.32^{\mathrm{a}}$ & $0.32^{\mathrm{b}}$ & $0.39^{\mathrm{a}}$ & $0.27^{\mathrm{b}}$ & $0.30^{\mathrm{b}}$ & $0.90^{\mathrm{a}}$ \\
Urea & $28.60 \pm$ & $43.16 \pm$ & $28.02 \pm$ & $38.36 \pm$ & $41.67 \pm$ & $30.45 \pm$ \\
& $2.06^{\mathrm{a}}$ & $2.62^{\mathrm{c}}$ & $2.30^{\mathrm{a}}$ & $1.12^{\mathrm{c}}$ & $1.44^{\mathrm{c}}$ & $1.73^{\mathrm{a}}$ \\
\hline
\end{tabular}

Values are mean \pm SD for $\mathrm{n}=5$, column values with different superscripts are significantly different $(\mathrm{p}<0.05)$ when compared to the control

Table 4. Effect of daily administration of EEAAR on ALT activity of streptozotocin-induced diabetic rats

\begin{tabular}{lcccccc}
\hline & \multicolumn{6}{c}{ Groups } \\
\cline { 2 - 7 } Tissues & Control & $\begin{array}{c}\text { Diabetic } \\
\text { control }\end{array}$ & $\begin{array}{c}125 \\
\mathrm{mg} / \mathrm{kg} \\
\text { b.wt }\end{array}$ & $\begin{array}{c}250 \\
\mathrm{mg} / \mathrm{kg} \\
\text { b.wt }\end{array}$ & $\begin{array}{c}500 \\
\mathrm{mg} / \mathrm{kg} \\
\text { b.wt }\end{array}$ & $\begin{array}{c}10 \mathrm{mg} / \mathrm{kg} \\
\text { b.wt } \\
\text { metformin }\end{array}$ \\
\hline Liver & $40.17 \pm$ & $75.43 \pm$ & $38.75 \pm$ & $428.00 \pm$ & $443.50 \pm$ & $35.08 \pm$ \\
(U/L) & $0.14^{\mathrm{a}}$ & $6.35^{\mathrm{b}}$ & $2.73^{\mathrm{a}}$ & $3.00^{\mathrm{d}}$ & $2.17^{\mathrm{d}}$ & $6.19^{\mathrm{a}}$ \\
Serum & $3.32 \pm$ & $30.69 \pm$ & $3.71 \pm$ & $45.26 \pm$ & $53.01 \pm$ & $3.29 \pm$ \\
(U/L) & $0.31^{\mathrm{a}}$ & $0.69^{\mathrm{c}}$ & $0.10^{\mathrm{a}}$ & $0.41^{\mathrm{d}}$ & $0.03^{\mathrm{b}}$ & $0.51^{\mathrm{a}}$ \\
\hline
\end{tabular}

Values are mean \pm SD for $\mathrm{n}=5$, column values with different superscripts are significantly different $(\mathrm{p}<0.05)$ when compared to the control

Table 5. Effect of EEAAR on AST activity of streptozotocininduced diabetic rats

\begin{tabular}{lcccccc}
\hline & \multicolumn{6}{c}{ Groups } \\
\cline { 2 - 8 } Tissues & Control & $\begin{array}{c}\text { Diabetic } \\
\text { control }\end{array}$ & $\begin{array}{c}25 \mathrm{mg} / \mathrm{kg} \\
\text { b.wt }\end{array}$ & $\begin{array}{c}250 \\
\mathrm{mg} / \mathrm{kg} \\
\text { b.wt }\end{array}$ & $\begin{array}{c}500 \\
\mathrm{mg} / \mathrm{kg} \\
\text { b.wt }\end{array}$ & $\begin{array}{c}10 \mathrm{mg} / \mathrm{kg} \\
\text { b.wt } \\
\text { metformin }\end{array}$ \\
\hline Liver & $15.06 \pm$ & $51.94 \pm$ & $380.17 \pm$ & $75.68 \pm$ & $10.38 \pm$ & $55.17 \pm$ \\
(U/L) & $0.11^{\mathrm{a}}$ & $0.23^{\mathrm{b}}$ & $0.47^{\mathrm{c}}$ & $0.62^{\mathrm{d}}$ & $0.47^{\mathrm{e}}$ & $1.01^{\mathrm{f}}$ \\
Serum & $3.68 \pm$ & $35.02 \pm$ & $66.96 \pm$ & $37.42 \pm$ & $30.93 \pm$ & $3.76 \pm$ \\
(U/L) & $0.26^{\mathrm{a}}$ & $0.57^{\mathrm{b}}$ & $0.25^{\mathrm{c}}$ & $0.15^{\mathrm{d}}$ & $0.21^{\mathrm{e}}$ & $0.49^{\mathrm{a}}$ \\
\hline
\end{tabular}

Values are mean $\pm S D$ for $n=5$, column values with different superscripts are significantly different $(\mathrm{p}<0.05)$ when compared to the control

Effect of seven-day daily administration of ethanolic extract of $A$. ataxacantha root on fasting blood glucose of streptozotocin - induced diabetic rats

There was a significant increase $(\mathrm{p}<0.05)$ in the blood glucose level on day 1 in all tested groups when compared with the control (Table 2). There was also an increase $(\mathrm{p}<0.05)$ in the blood glucose level on days 3 and 7 in all the groups $(\geq 226.00 \pm 28.23)$ except the groups that received $125 \mathrm{mg} / \mathrm{kg}$ body weight (b.wt.) of EEAAR and $10 \mathrm{mg} / \mathrm{kg}$ b.wt. of metformin respectively, in which there was no significant difference $(\leq 110.01 \pm$ 9.64) when compared to the control (106.33 \pm 4.13$)$.

The effects of daily administration of EEAAR for seven days on some kidney parameters of streptozotocin induced diabetic rats were analysed (Table 3$)$. There was an increase $(p<0.05)$ in the serum urea and creatinine in all groups except in those that received $125 \mathrm{mg} / \mathrm{kg}$ b.wt. of EEAAR and $10 \mathrm{mg} / \mathrm{kg} \mathrm{b}$.wt. of metformin, which gave no significant difference $(p>0.05)$ compared to the control. 
Table 6. Effect of administration of EEAAR on lipid profile and atherogenic index of streptozotocin-induced diabetic rats

\begin{tabular}{|c|c|c|c|c|}
\hline \multirow{2}{*}{ Groups } & \multicolumn{4}{|c|}{ Parameters } \\
\hline & $\mathrm{TC}(\mathrm{mg} / \mathrm{dl})$ & $\mathrm{HDL}(\mathrm{mg} / \mathrm{dl})$ & $\mathrm{LDL}(\mathrm{Mg} / \mathrm{dl})$ & Atherogenic index (LDL/HDL) \\
\hline Control & $91.66 \pm 8.54^{a}$ & $23.23 \pm 2.34^{a}$ & $56.73 \pm 4.91^{a}$ & $2.39 \pm 0.11^{\mathrm{a}}$ \\
\hline Diabetic control & $151.14 \pm 2.79^{b}$ & $5.52 \pm 0.48^{b}$ & $130.66 \pm 5.55^{b}$ & $24.72 \pm 2.94^{\mathrm{b}}$ \\
\hline $125 \mathrm{mg} / \mathrm{kg}$ b.wt. & $94.03 \pm 0.54^{a}$ & $29.75 \pm 0.31^{c}$ & $25.46 \pm 2.16^{\mathrm{a}}$ & $2.16 \pm 0.20^{\mathrm{a}}$ \\
\hline $250 \mathrm{mg} / \mathrm{kg}$ b.wt. & $101.04 \pm 2.14^{\mathrm{a}}$ & $36.62 \pm 1.07^{\mathrm{d}}$ & $25.86 \pm 3.02^{c}$ & $1.98 \pm 0.05^{\mathrm{a}}$ \\
\hline $500 \mathrm{mg} / \mathrm{kg}$ b.wt. & $104.81 \pm 4.38^{\mathrm{ab}}$ & $44.25 \pm 2.36^{\mathrm{c}}$ & $40.62 \pm 3.63^{c}$ & $3.18 \pm 0.30^{\mathrm{a}}$ \\
\hline $10 \mathrm{mg} / \mathrm{kg}$ b.wt. metformin & $106.68 \pm 8.92^{\mathrm{a}}$ & $45.43 \pm 0.22^{c}$ & $24.28 \pm 2.14^{\mathrm{b}}$ & $3.08 \pm 0.10^{\mathrm{a}}$ \\
\hline
\end{tabular}

Values are mean $\pm S D$ for $n=5$, column values with different superscripts are significantly different $(\mathrm{p}<0.05)$ when compared to the control

Table 7. Effect of administration of ethanolic root extract of Acacia ataxacantha on MDA concentration of streptozotocin-induced diabetic rats

\begin{tabular}{|c|c|c|c|c|c|c|}
\hline \multirow{2}{*}{ Tissues } & \multicolumn{6}{|c|}{ Groups } \\
\hline & Control & Diabetic control & $125 \mathrm{mg} / \mathrm{kg}$ b.wt & $250 \mathrm{mg} / \mathrm{kg}$ b.wt & $500 \mathrm{mg} / \mathrm{kg}$ b.wt & $10 \mathrm{mg} / \mathrm{kg}$ b.wt metformin \\
\hline $\operatorname{Liver}(\mathrm{U} / \mathrm{L})$ & $143.00 \pm 2.00^{\mathrm{a}}$ & $158.10 \pm 2.15^{\mathrm{b}}$ & $144.16 \pm 1.78^{\mathrm{a}}$ & $222.74 \pm 2.04^{\mathrm{c}}$ & $201.11 \pm 1.14^{\mathrm{c}}$ & $144.66 \pm 2.36^{\mathrm{a}}$ \\
\hline $\operatorname{Serum}(\mathrm{U} / \mathrm{L})$ & $2.80 \pm 0.12^{\mathrm{a}}$ & $4.41 \pm 0.33^{b}$ & $3.39 \pm 0.23^{\mathrm{a}}$ & $4.16 \pm 0.16^{\mathrm{b}}$ & $6.79 \pm 0.04^{\mathrm{a}}$ & $3.47 \pm 0.27^{\mathrm{a}}$ \\
\hline
\end{tabular}

Values are mean $\pm S D$ for $n=5$, column values with different superscripts are significantly different $(\mathrm{p}<0.05)$ when compared to the control

Table 8. Effect of administration of ethanolic extract of Acacia ataxacantha root on liver, serum and pancreatic SOD activities of streptozotocin-induced diabetic rats

\begin{tabular}{lcccccc}
\hline \multirow{2}{*}{ Tissues } & \multicolumn{5}{c}{ Groups } \\
\cline { 2 - 7 } & Control & Diabetic control & $125 \mathrm{mg} / \mathrm{kg} \mathrm{b} . w t$. & $250 \mathrm{mg} / \mathrm{kg} \mathrm{b.wt}$ & $500 \mathrm{mg} / \mathrm{kg}$ b.wt & $10 \mathrm{mg} / \mathrm{kg}$ b.wt metformin \\
\hline Liver & $592.67 \pm 1.13^{\mathrm{a}}$ & $124.63 \pm 4.70^{\mathrm{b}}$ & $741.27 \pm 2.51^{\mathrm{c}}$ & $620.30 \pm 2.00^{\mathrm{d}}$ & $905.10 \pm 1.00^{\mathrm{e}}$ & $601.16 \pm 4.04^{\mathrm{f}}$ \\
Pancreas & $508.00 \pm 1.04^{\mathrm{a}}$ & $104.11 \pm 0.24^{\mathrm{b}}$ & $535.05 \pm 2.41^{\mathrm{c}}$ & $536.30 \pm 1.15^{\mathrm{c}}$ & $518.13 \pm 3.20^{\mathrm{d}}$ & $527.02 \pm 1.71^{\mathrm{c}}$ \\
Serum & $190.54 \pm 0.45^{\mathrm{ac}}$ & $160.01 \pm 0.68^{\mathrm{b}}$ & $184.16 \pm 1.44^{\mathrm{c}}$ & $155.10 \pm 0.94^{\mathrm{b}}$ & $209.98 \pm 0.95^{\mathrm{d}}$ & $196.67 \pm 12.14^{\mathrm{f}}$ \\
\hline
\end{tabular}

Values are mean $\pm S D$ for $\mathrm{n}=5$, column values with different superscripts are significantly $(\mathrm{p}<0.05)$ when compared to the control

Effects of daily administration of ethanolic extract of $A$. ataxacantha root on the activities of $A L T$ and $A S T$ in streptozotocin - induced diabetic rats

The effects of daily administration of ethanolic root extract of $A$. ataxacantha on ALT and AST activities of streptozotocin-induced diabetic rats are presented in Tables 4 and 5 respectively. There was an increase $(\mathrm{p}<0.05)$ in the ALT and AST activities of the liver and serum of rats in all the groups except in those that received $125 \mathrm{mg} / \mathrm{kg}$ b.wt. of EEAAR and $10 \mathrm{mg} / \mathrm{kg}$ b.wt. of metformin, which had no difference $(p>0.05)$ compared to the control.

Effects of daily administration of ethanolic extract of $A$. ataxacantha root on lipid profile and atherogenic index of streptozotocin - induced diabetic rats

The effect of daily administration of ethanolic extract of $A$. ataxacantha root on lipid profile and atherogenic index of streptozotocin - induced diabetic rats were examined (Table 6). There was no difference $(p>0.05)$ in the serum total cholesterol in all the groups except the diabetic control group, which had an increase $(\mathrm{p}<0.05)$ when compared with the control. There was a significant increase $(\mathrm{p}<0.05)$ in all groups in the high-density lipoprotein except the group that was diabetic, which had a significant decrease $(\mathrm{p}<0.05)$ compared to the control. There was a decrease $(p>0.05)$ in the low density lipoprotein in all the groups except for the diabetic control, which had an increase $(\mathrm{p}<0.05)$ compared to the control. There was no difference $(p>0.05)$ in the atherogenic indices in all treated groups compared to the control, but there was a significant increase $(\mathrm{p}<0.05)$ in the diabetic control compared to the non-diabetic control.
Effects of daily administration of ethanolic extract of $A$. ataxacantha root on liver and pancrease MDA concentration in streptozotocin - induced diabetic rat

The effects of daily administration of ethanolic extract of $A$. ataxacantha root daily for seven days on liver and pancrease MDA concentration of streptozotocin-induced diabetic rats are presented in Table 7 . There was no significant difference $(p>0.05)$ in the MDA concentration of liver and pancreas of rats administered $125 \mathrm{mg} / \mathrm{kg}$ b.wt. of EEAAR and $10 \mathrm{mg} / \mathrm{kg}$ b.wt. of metformin (reference drug) compared to the control, but there was a significant increase $(\mathrm{p}<0.05)$ in the diabetic control group and among those that received $250 \mathrm{mg} / \mathrm{kg}$ and $500 \mathrm{mg} / \mathrm{kg}$ b.wts. of EEAAR.

Effects of administration of ethanolic extract of $A$. ataxacantha root on liver and pancreas superoxide dismutase activities of streptozotocin - induced diabetic rats

The effects of administration of ethanolic root extract of A. ataxacantha on hepatic and pancreatic superoxide dismutase of streptozotocin - induced diabetic rats were examined (Table 8). There was a significant increase $(\mathrm{p}<$ 0.05 ) in the superoxide dismutase activities of rat liver and pancreas in all the groups except diabetic control group that had a significant decrease $(\mathrm{p}<0.05)$ compared to the control.

\section{Discussion}

In the present study, $A$. ataxacantha root was selected for normoglycaemic, normolipidaemic and antioxidant activities owing to its traditional uses. Therefore, the study was undertaken to verify its 
148

traditionally claimed uses. Phytochemical analysis of $A$. ataxacantha revealed the presence of alkaloids, polyphenols, flavoniods, saponins, taninns and terpenoids. Flavonoids are known to regenerate the damaged cells in diabetic mice and found to stimulate insulin secretion or possess an insulinlike effect (Rao et al., 1997; Eidi et al., 2005; Khandelwal, 2007; Ghosh et al., 2009). Effects of polyphenols such as flavonoids on pancreatic $\beta$-cells leading to their proliferation and stimulation for insulin secretion have been proposed by Mahesh and Menon (2004) as the mechanism by which medicinal plants used in the treatment of diabetes mellitus reduce hyperglycaemia in streptozotocin - induced diabetic rats.

The results revealed that the ethanolic extract of $A$. ataxacantha root reduced blood glucose in STZ-induced hyperglycemic rats to levels comparable to the reference clinical drug metformin after 7 days. This is in agreement with the findings of previous study on the ethanolic extract of $A$. ataxacantha bark (Arise et al., 2014). The lower dose $125 \mathrm{mg} / \mathrm{kg}$ body weight of $A$. ataxacantha root extract was the most effective dosage, reducing the blood glucose almost to the normoglycemic level by day 7 of administration. However, higher doses of 250 and $500 \mathrm{mg} / \mathrm{kg}$ body weight of EEAAR did not show any hypoglycaemic activity; this may be due to high toxicity of the extract at high doses, resulting in overwhelming reduction in the biological active component involved in hypoglycaemia. The mechanism of the antidiabetic properties of $A$. ataxacantha root extract might be through the promotion of glucose uptake or inhibition of hepatic gluconeogenesis. Direct effect in the absence of insulin indicate that the extract has either insulin-like effect on the skeletal muscle or direct stimulatory effect on the enzymes involved in the pathways of glucose uptake in the presence of insulin receptor in the muscle or increase in the number of insulin receptors (Liu $e t$ al., 2008).

Elevated levels of serum urea and creatinine were observed, which may be due to renal damage caused by abnormal glucose regulation or elevated glucose and glycosylated protein tissues levels (Lal et al., 2009). Significant increase in serum urea and creatinine levels were observed in diabetic rats compared to control rats, which indicated impaired renal function in diabetic rats. The treatment with $125 \mathrm{mg} / \mathrm{kg}$ body weight of EEAAR decreased the above mentioned parameters significantly $(\mathrm{p}$ $<0.05$ ) compared to diabetic control rats.

Serum AST and ALT activities were used as markers of tissue damage. Diabetes mellitus induction by administration of STZ produces an experimental damage due to its toxic metabolites (Zhang and Swaan, 1999). AST and ALT are enzymes found mainly in the cell of the liver, heart, skeletal muscle, kidney and pancreas, and to a lesser amount, in red blood cells. Their serum concentrations are proportional to the amount of cellular leakage or damage and are released into serum in larger quantities when any one of these tissue is compromised. The reduction of AST and ALT activities at the dose of $125 \mathrm{mk} / \mathrm{kg}$ body weight of EEAAR and $10 \mathrm{mg} / \mathrm{kg}$ body weight of metformin is an indication of repair of tissue damage induced by diabetic complications. This is in agreement with Shahidi et al. (1992) who reported that serum transminases returned to normal activities with the healing of tissue parenchyma and regeneration of hepatocyted and renal tissues. The EEAAR induced suppression of increased ALT and AST activities.

Significant reduction in the activities of these enzymes in $125 \mathrm{mg} / \mathrm{kg}$ body weight of EEAAR treated diabetic rats may be because of revival of insulin secretion into circulation or decreased cellular damage. These reductions may also be the consequence of improvement in the carbohydrate, fat and protein metabolism due to the therapy of EEAAR. This could be due to the presence of flavonoids in the EEAAR, which are reported to be hepatoprotective agents (Sivajothi et al., 2008). However, the elevated serum ALT activity at the doses of 250 and 500 $\mathrm{mg} / \mathrm{kg}$ b.wt. might imply the toxicity of the extract at these higher doses, possibly as a result of damage to the membranes of liver cells and consequent leakage of hepatic cytosolic contents. The observed elevated ALT activity in the liver could indicate that the extract stimulates de novo synthesis of the enzyme.

In the present study, STZ-induced diabetes developed into hyperlipidemi,a which is in agreement with previous observations (Fatima et al., 2010; Sireesha et al., 2011). A variety of alterations in metabolic and regulatory mechanisms due to insulin deficiency or due to insulin resistance are responsible for the observed accumulation of lipids (Rajalingam et al., 1993). The EEAAR at all doses significantly reduced the LDL-C and atherogenic index in treated diabetic rats compared to untreated diabetic rats; it also brought the TC near normal levels, with an increase of HDL-C in treated diabetic rats compared to untreated diabetic rats. This may be due to the insulinotropic effects or insulin secretagogue activity of EEAAR. The decrease in atherogenic index is due to an increase in HDL-C levels after treatment. HDL-C is known to play an important role in the transport of cholesterol from peripheral cells to the liver by a pathway termed reverse cholesterol transport, and is considered to be a cardio-protective lipid.

STZ, in addition to inducing diabetes, also induces oxidative stress or relative overload of oxidants e.g. reactive oxygen species (Wright, 1999). Treatment with $125 \mathrm{mg} / \mathrm{kg}$ body weight EEAAR brought back lipid peroxidation markers (MDA) to normal levels in the liver and pancreas, which could be as a result of improved glycaemic control and antioxidants status. This study shows that EEAAR has significant glucose reducing property in STZ-induced diabetic rats at the dose of $125 \mathrm{mg} / \mathrm{kg}$ body weight. Increased lipid peroxidation in a diabetic state can be due to increased oxidative stress in the cell as a result of depletion of antioxidant scavenger systems. Lipid peroxidation in the diabetic tissues showed a decreased activity of SOD and increase MDA, which play an important role in scavenging the toxic intermediate of incomplete oxidation. Studies in the past have reported that the activity of SOD is low in diabetes mellitus (FeilletCoudray et al., 1999). The result of increased activities of SOD in the present study suggests that EEAAR contains a free radical scavenging activity, which could exert a beneficial effect against pathological alterations caused by the presence of $\mathrm{O}_{2}{ }^{-}$and $\mathrm{OH}^{-}$. This action could involve mechanisms related to scavenging activity of EEAAR. 


\section{Conclusions}

The ethanolic extract of Acacia ataxacantha root possess antioxidant and normoglycaemic properties, inhibiting hepatic glucose formation on STZ-induced diabetic rats, optimally at a dosage of $125 \mathrm{mg} / \mathrm{kg}$ body weight. The extract was highly effective in managing complications like hyperlipidaemia associated with diabetes mellitus. However, the extract may not be safe at higher and repeated doses.

\section{Acknowledgments}

This research received no specific grant from any funding agency in the public, commercial, or not-for-profit sectors.

\section{References}

American Diabetes Association (ADA) (2012). Diagnosis and classification of diabetes mellitus. Diabetes care 35:64-70.

Arise RO, Ganiyu AI, Oguntibeju OO (2014). Lipid profile, antidiabetic and antioxidant activity of Acacia ataxacantha bark extract in streptozotocin-induced diabetic rats. In: Oguntibeju $\mathrm{O}$ (Ed). Antioxidant-Antidiabetic Agents and Human Health. http://dx.doi.org/10.5772/57151.

Burstein M, Soholnick H, Morfin R (1970). Rapid method for the isolation of lipoproteins from human serum by precipitation with polyanions (Review). Journal of Lipid Research 11:583595.

Eidi M, Eidi A, Zamanizadeh H (2005). Effect of Salivia officinalis L. leaves on serum glucose and insulin in healthy and streptozotocin-induced diabetic rats. Journal of Ethnopharmacology 100:310-313.

Fatima SS, Rajasekhar MD, Kumar KV, Kumar MT, Babu KR, Rao CA (2010). Antidiabetic and antihyperlidemic activity of ethylacetate:Isopropanol (1:1) fraction of Vernonia anthelmintica seeds in streptozotocin induced diabetic rats. Food and Chemical Toxicology 48(2):495-501.

Feillet-Coudray C, Rock E, Coudray C, Grzelkowska K, AzaisBraesco V, Dardevet D, Mazur A (1999). Lipid peroxidation and antioxidant status in experimental diabetes. Clinica Chimica Acta 842:31-43.

Foster CS, Dunn O (1973). Stable reagents for determination of serum triglycerides by a colorimetric Hantzsch condensation method. Clinica Chimica Acta 9:338-340.

Friedewald WT, Levi RI, Fredrickson DS (1972). Estimation of the concentration of low-density lipoprotein cholesterol in plasma, without use of the preparative ultracentrifuge Clinical Chemistry 18:499-502.

Gayathri M, Kannabiran K (2008). Hypoglycemic activity of Hemidesmus indicus on streptozotocin-induced diabetic rats. International Journal of Diabetes in Developing Countries 28:6-16.
Ghosh D, Bera TK, Chatterjee K, Ali KM, De D (2009). Antidiabetic and antioxidant effects of aqueous extract of seed of Psoralea corylifolia (somraji) and seed of Trigonella foenumgraecum L., (methi) in separate and composite manner in streptozotocin-induced diabetic male Albino rat. Tropical Journal of Pharmaceutical Research 1:1-10.

Jerald E, Banyan O, Edwin S, Ahmad S, Jamalludin S (2009). Antidiabetic activity of few medicinal plants vs their combination of alloxan-induced diabetic rats. Journal of Pharmacy Research 2:1760-1763.

Kala SMJ, Tresina PS, Mohan VR (2012a). Antioxidant, antihyperlipidaemic and antidiabetic activity of Eugenia floccosa Bedd leaves in alloxan-induced diabetic rats. Journal of Basic and Clinical Pharmacy 3:235-240.

Kala SMJ, Tresina PS, Mohan VR (2012b). Antioxidant, antihyperlipidaemic and antidiabetic activity of Eugenia singamattina Bedd leaves in alloxan induced diabetic rats. International Journal of Pharmaceutical Sciences 4:412-416.

Khandelwal KR (2007). Practical Pharmacognosy. 18th ed. Pune India: Nirali publication.

Kumar S, Kumar V, Prakash O (2011a). Antidiabetic and antihyperlipidemic effects of Dillenia indica (L.) leaves extract. Brazilian Journal of Pharmaceutical Sciences 47(2):1-6.

Kumar S, Kumar V, Prakash O (2011b). Antidiabetic, hypolipidemic and histopathological analysis of Dillenia indica (L.) leaves extract on alloxan-induced diabetic rats. Asians Pacific Journal of Tropical Medicine 4(5):347-352.

Lal SS, Sukla Y, Singh A, Anderiyas EA, Lall AM (2009). Hyperuricemia, high serum urea and hypoproteinemia are the risk factors for diabetes. Asian Journal of Medical Sciences 1:33-34.

Lynette D, Barbara J (1981). Acacia, a field guide to the identification of the species of southern Africa (1st ed). Centaur pp 121.

Liu F, Kim JK, Li Y, Liu XQ, Li J, Chen X (2001). An extract of Lagerstroemia speciosa L. has insulin-like glucose uptakestimulatory and adipocyte differentiation-inhibitory activities in 3T3-L1 cells. The Journal of Nutrition 131(9): 2242-2247.

Mahesh T, Menon VP (2004). Quercetin alleviates oxidative stress in streptozotocin - induced diabetic rats. Phytotherapy Research 18:123-127.

Maritim AC, Sanders RA, Watkins JB (2003). Diabetes, oxidation stress, and antioxidants: a review. Journal of Biochemical and Molecular Toxicology 17:24-38.

Maruthupandian A, Mohan VR (2011). Antidiabetic, antihyperlipidaemic and antioxidant activity of Pterocarpus marsupus Roxb in alloxan-induced diabetic rats. International Journal of Pharm Tech Research 3:1681-1687.

Misra HP, Fridovich I (1972). The role of superoxide anion in the autooxidation of epinephrine and a simple assay for superoxide dismutase. Journal of Biological Chemistry 247:3170-3175. 
Sivajothi V, Dey A, Jayakar B, Rajkapoor B (2008). Antihyperglycemic, antihyperlipidemic and antioxidant effect of Phyllanthus rheedii on streptozotocin induced diabetic rats. Iranian Journal of Pharmaceutical Research 7(1):53-59.

Varley H (1976). Practical clinical biochemistry. Arnold Heinemann Publication Pvt. Ltd pp 452.

Varshney R, Kale RK (1990). Effect of calmodulin antagonist on radiation-induced lipid peroxidation in microsome. International Journal of Radiation Biology 58:733-743.

Wolff SP (1967). Diabetes mellitus and free radicals: free radicals, transition metals and oxidative stress in the aetiology of diabetes mellitus and complications. British Medical Bulletin 49:642-652.

Wright JR, Abraham C, Dickson BC, Yang H, Morrison CM (1999). Streptozotocin dose-response curve in tilapia, a glucose-responsive teleost fish. General and Comparative Endocrinology114(3):431-440.

Yakubu MT, Akanji MA, Oladiji AT (2005). Aphrodisiac potentials of the aqueous extract of Fadogia agretis (Schweinf. Ax. Heirn) stem in male albino rats. Asian Journal of Andrology 7:399-404.

Zhang EY, Swaan PW (1999). Determination of membrane protein glycation in diabetic tissue. American Association of Pharmaceutical Scientists 20:1-7.

Zlakis A, Zak B, Boyle A (1953). A new method for the determination of serum cholesterol. Journal of Laboratory and Clinical Medicine 4:486-492.
Antihyperglycemic and hypolipidemic activities of Setaria italica seeds in STZ diabetic rats. Pathophysiology 18:159164. 